Revista de Biología Marina y Oceanografía

Vol. 48, №3: 521-534, diciembre 2013

DOI 10.4067/S0718-19572013000300010

Article

\title{
Redescription of the sea anemones Anthopleura hermaphroditica and Bunodactis hermafroditica (Cnidaria: Anthozoa: Actiniaria) from Chile
}

Redescripción de las anémonas de mar Anthopleura hermaphroditica y Bunodactis hermafroditica (Cnidaria: Anthozoa: Actiniaria) de Chile

\section{Carlos Spano $^{1,2}$, Nicolás Rozbaczylo ${ }^{2}$, Vreni Häussermann ${ }^{3,4}$ and Ricardo Bravo ${ }^{1}$}

${ }^{1}$ Facultad de Ciencias del Mar y de Recursos Naturales, Universidad de Valparaíso, Casilla 5080, Reñaca, Viña del Mar, Chile. spanoperez.ca@gmail.com

${ }^{2}$ Departamento de Ecología, Facultad de Ciencias Biológicas, Pontificia Universidad Católica de Chile, Casilla 114-D, Santiago, Chile

${ }^{3}$ Escuela de Ciencias del Mar, Facultad de Recursos Naturales, Pontificia Universidad Católica de Valparaíso, Av. Altamirano 1480, Valparaíso, Chile

${ }^{4}$ Huinay Scientific Field Station, Casilla 462, Puerto Montt, Chile

\begin{abstract}
Resumen.- Debido a la ambigua definición de sus caracteres diagnósticos, las anémonas de mar chilenas Anthopleura hermaphroditica y Bunodactis hermafroditica han sido confundidas en reiteradas ocasiones. Examinando la anatomía externa e interna de varios ejemplares recolectados entre Antofagasta y Chiloé, se re-describe y compara ambas especies en relación a su historia sinonímica. Aun siendo muy similares, A. hermaphroditica y B. hermafroditica pueden ser distinguidas por los patrones de coloración del disco oral, el desarrollo de las verrugas, la presencia de zooxantelas y los cnidocistos de la columna y filamentos mesenteriales. En base a estos criterios, la autoría de Bunodactis hermafroditica pertenece a Carlgren (1959) pero debido a que el material tipo no corresponde con la descripción, se designa un neotipo que contiene las características señaladas por dicho autor. Aunque se cuestiona la validez de los acrorragios para diferenciar géneros, se proponen modificaciones a la terminología empleada en las diagnosis de Anthopleura y Bunodactis. A partir de esto se rechaza la sinonimización de los géneros Gyractis y Bunodactis, considerando este último un género válido hasta que se realice una adecuada revisión del material tipo de Aulactinia. Por otro lado, las marcadas diferencias anatómicas observadas entre poblaciones de Anthopleura hermaphroditica sugieren la presencia de al menos dos especies distintas.
\end{abstract}

Palabras clave: Actiniidae, taxonomía, intermareal, Pacífico suroriental

\begin{abstract}
The Chilean sea anemones Anthopleura hermaphroditica and Bunodactis hermafroditica have been confused repeatedly due to ambiguity in the definition of their diagnostic features. The present article re-describes and compares both species in relation to their synonymic history by examining the external and internal anatomy of several specimens collected between Antofagasta and Chiloé. Although very similar, A. hermaphroditica and B. hermafroditica can be distinguished by the coloration patterns of the oral disc, development of verrucae, presence of zooxanthellae, and the cnidae of the column and the mesenterial filaments. Based on these differences, the authorship of Bunodactis hermafroditica belongs to Carlgren (1959) but because the type material does not match with the description; we designate a neotype that contains the features identified by this author. While the validity of acrorhagi to differentiate genera is questioned, some amendments to the terminology used in the diagnosis of Anthopleura and Bunodactis are proposed. Hence, we reject the synonymization of the genera Gyractis and Bunodactis, considering the latter as a valid genus until a proper review with the type material of Aulactinia is made. In addition, the remarkable anatomical differences observed among populations of Anthopleura hermaphroditica suggest the presence of at least two distinct species.
\end{abstract}

Key words: Actiniidae, taxonomy, intertidal, Southeast Pacific

\section{INTRODUCTION}

Although few characteristics differentiate their members, the family Actiniidae includes an extraordinary diversity of species (Carlgren 1949, McCommas 1991). Since Carlgren's (1949) key, actiniid genera have been distinguished almost exclusively based on morphological features of the column which, to date, have been discussed in several papers (Den Hartog 1987, Belém \& Pinto 1990, Riemann-Zürneck \& Gallardo 1990, Daly 2004a, Daly \& Den Hartog 2004, 
Häussermann 2004). Anthopleura Duchassaing \& Michelotti, 1860, Bunodactis Verrill, 1899, Aulactinia Verrill, 1864, and Gyractis Boveri, 1893 have been traditionally differentiated by the presence of marginal spherules or acrorhagi. These characteristics, however, had been frequently confused in descriptions and it was not until the revision of Daly (2003) that these structures were finally defined. When Carlgren (1959) separated Anthopleura hermaphroditica (Carlgren, 1899) from Bunodactis hermafroditica (Carlgren, 1959), the only difference he stated at that time was the presence of marginal spherules and thus, these species have been treated as synonyms and as different species in subsequent determinations. While the description of these two species have been recently reviewed (Yanagi \& Daly 2004, Sanamyan et al. 2009), so far no study has defined them comparatively. The present paper redescribes Anthopleura hermaphroditica and Bunodactis hermafroditica, including in vivo observations, anatomy and cnidae data. Furthermore, the diagnostic characters of both species, as well as their authorship and generic assignment, are discussed.

\section{MATERIALS AND METHODS}

Between March and June 2012, over 200 specimens of Anthopleura hermaphroditica and Bunodactis hermafroditica were collected from the intertidal zone along the Chilean coast, from Antofagasta (2339' $S$; $\left.70^{\circ} 25^{\prime} \mathrm{W}\right)$ to Chiloé Island ( $\left.41^{\circ} 51 \mathrm{~S} ; 7^{\circ} 49^{\prime} \mathrm{W}\right)$ (Fig. 1). The specimens were photographed both in the field, either in situ or in an aquarium, and in the laboratory with a Nikon ${ }^{\circledR}$ SMZ-10A stereomicroscope. Specimens were relaxed with menthol crystals or $6-8 \% \mathrm{MgCl}_{2}$ and fixed in Bouin's solution (for histology) or in 8-10\% seawater formalin. For the histological examination, 12 and 8 specimens of $A$. hermaphroditica and $B$. hermafroditica, respectively, were embedded in paraffin, sectioned at 5 and $7 \mu \mathrm{m}$, and stained with Masson's trichrome, with modifications of Spano \& Flores (2013).

The cnidae from 26 and 9 specimens of Anthopleura hermaphroditica and Bunodactis hermafroditica, respectively, were examined with a Nikon ${ }^{\circledR}$ OptiPhot-2 light microscope (1000X oil immersion) and photographed with a CoolSNAP-Pro camera connected to Image-Pro Plus software, both of Media Cybernetics ${ }^{\circledR}$. From each individual, 40 capsules (whenever possible) were measured per type and per tissue. Cnidae measurements were statistically compared between populations, using Minitab® 15 software. In most cases the normality assumption was not fulfilled and, therefore, non-

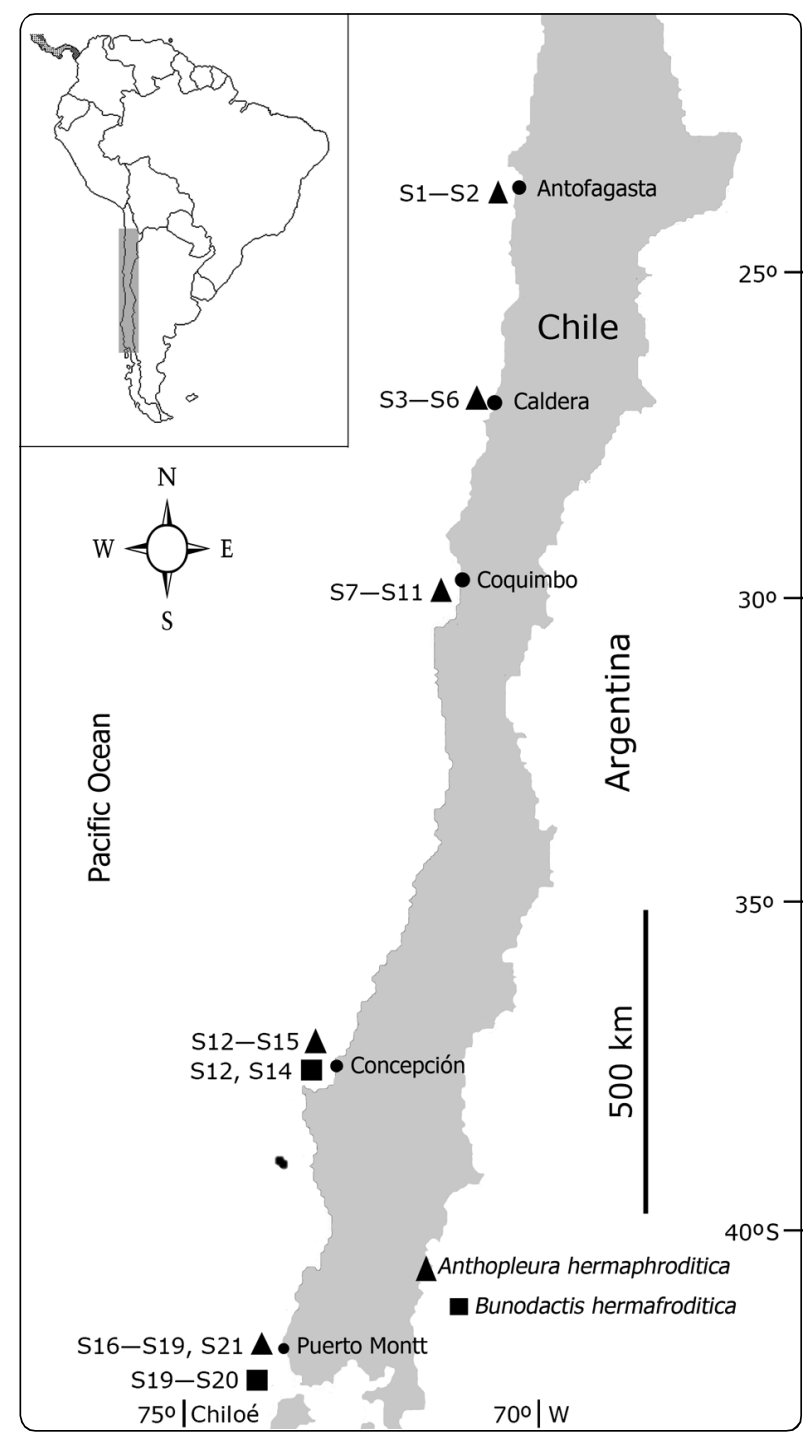

Figure 1. Sampling sites of the intertidal zone from Antofagasta to Chiloé / Sitios de muestreo de la zona intermareal desde Antofagasta hasta Chiloé

parametric analyses, such as Kruskal-Wallis test, were required. Additionally, semi-permanent slides were prepared in the field using Yanagi's technique (1999) fide Häussermann \& Försterra (2009) to observe discharge cnidae. Nematocyst terminology follows that of Schmidt (1972) and England (1991).

The studied specimens were deposited in the 'Colección de Flora y Fauna Profesor Patricio Sánchez. Reyes' of the Pontificia Universidad Católica de Chile, Santiago (SSUC); Zoologische Staatssammlung München, Germany (ZSM); additional specimens were kept by CS. 


\section{Results}

Anthopleura Duchassaing \& Michelotti, 1860

Actiniidae with well-developed pedal disc. Column with adhesive verrucae arranged in longitudinal rows. Acrorhagi present; may sit inside fosse or atop marginal projections. Fosse deep. Tentacles simple, conical, hexamerously or irregularly arranged, with ectodermal longitudinal muscles. At least two well-developed siphonoglyphs. Marginal sphincter muscle diffuse to circumscript; retractor muscles diffuse or restricted. In adults, numerous or all mesenteries perfect and fertile. Mesenteries more numerous proximally than distally in some specimens. Cnidom: spirocysts, basitrichs, holotrichs, microbasic $b$-mastigophores, microbasic $p$ mastigophores. (Diagnosis from Daly \& den Hartog 2004, with changes in bold)

\section{Anthopleura hermaphroditica (CARLgRen, 1899)}

Bunodes hermaphroditicus Carlgren 1899: 23.

Anthopleura hermaphroditica: Carlgren 1927: 32; Häussermann 1998: 83-91; Häussermann \& Försterra 2009: 252; Yanagi \& Daly 2004: 408-422 (in part); Schories et al. 2011:304-314.

Anthopleura hermafroditica: Carlgren 1949: 54; Carlgren 1959: 22

NOT Anthopleura handi: England 1987: 245-248; 1992: 66.

Examined material (all from intertidal): 1 specimen (SSUC 7757), Rada de Antofagasta (S1: $23^{\circ} 39^{\prime} \mathrm{S} ; 7^{\circ} 25^{\prime} \mathrm{W}$ ), 15.6.2012; 1 specimen (SSUC 7756), Pozas Los Gringos (S2: 234'ㄱ' $\left.70^{\circ} 26^{\prime} \mathrm{W}\right), 14.6 .2012$; 1 specimen (SSUC 7754), Escollo El Pulpo (S3: 2701'S; 7051'W), 18.5.2012; 1 specimen (SSUC 7755), Playa Brava (S4: 2703'S; 7050'W), 19.5.2012; 4 specimen (ZSM 20130507), Puerto de Caldera (S5: 2703'S; 7051'W), 17.5.2012; 1 specimen (SSUC 7753), Bahía Inglesa (S6: 2708'S; 7051'W), 18.5.2012; 1 specimen

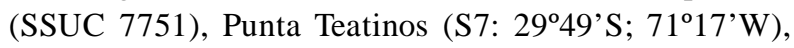
30.4.2012; 2 specimen (ZSM 20130508), Fuerte Lambert (S8: 295' 'S; 71²2'W), 1.5.2012; 1 specimen (SSUC 7752), Playa La Herradura (S9: 2958'S; 71²2' W), 1.5.2012; 1 specimen (SSUC 7750), Tongoy (S10: 30 $15^{\prime} \mathrm{S} ; 7^{\circ} 29^{\prime} \mathrm{W}$ ), 28.4.2012; 2 specimen (ZSM 20130509), Puerto Aldea (S11: 30¹7'S; 71³6'W), 28.4.2012; 1 specimen (SSUC 7749), Playa Merquiche (S12: 36²9'S, 72'54'W), 15.4.2012; 4 specimen (ZSM 20130510), Puntilla Coliumo (S13: 36³1'S; 7257'W), 12.4.2012; 1 specimen (SSUC 7747), Playa Cocholgüe (S14: 36³6'S; 7258'W), 12.4.2012; 1 specimen
(SSUC 7748), Punta Lavapié (S15: 3708'S; 73³5'W), 14.4.2012; 2 specimen (ZSM 20130511), Punta Pilluco (S16: 4130'S; 7253'W), 24.3.2012; 2 specimen (ZSM 20130512),

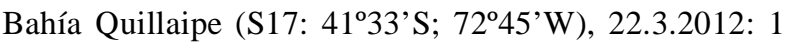
specimen (SSUC 7742), Punta Metri (S18: 4136'S; 72'42’W), 21.3.2012; 1 specimen (SSUC 7744), Punta (Faro)

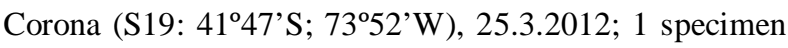
var. eton (SSUC 7743), Playa Lechagüa (S21: 41'52'S; 7352’W), 24.3.2012.

Examined type material.- Bunodes hermaphoditicus Carlgren, 1898 (Zoologisches Museum Hamburg C1496), Talcahuano (36 $\left.6^{\circ} 74^{\prime} \mathrm{S} ; 7^{\circ} 13^{\prime} \mathrm{W}\right)$; Bunodes hermaphoditicus Carlgren, 1898 (Naturhistoriska Rikmuseet 1177), Talcahuano (36 $\left.6^{\circ} 74^{\prime} \mathrm{S} ; 7^{\circ} 13^{\prime} \mathrm{W}\right)$; Cribrina hermaphroditica McMurrich, 1904 (Museum für Naturkunde der Humboldt

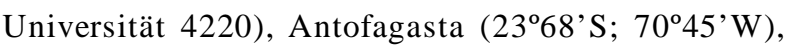

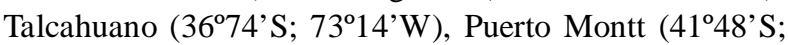
72 $96^{\prime}$ 'W); Anthopleura hermafroditica Carlgren, 1959 (Museum of Natural History in Oslo B1076), Seno Reloncavi, Punta Pilluco (41 50 'S; 7290'W); Bunodactis hermafroditica Carlgren, 1959 (identified as Anthopleura hermaphroditica, see Discussion) (Museum of Natural History in Oslo B1075), Seno Reloncavi, Punta Pilluco (41 50 's; $\left.72^{\circ} 90^{\prime} \mathrm{W}\right)$.

Differential diagnosis: Brown, medium to small size, short cylinder-shaped species with oral disc slightly wider than pedal disc and column up to $17 \mathrm{~mm}$ in diameter. Oral disc may present opaque marks over mesenterial insertions with or without greenish-white spots along tentacles. Marginal sphincter circumscript, retractor muscles diffuse and mesenteries more numerous proximally than distally. Hermaphroditic viviparous; zooxanthellae in gastrodermis.

External anatomy: Size.- Pedal disc diameter up to $17 \mathrm{~mm}$, typically $6 \mathrm{~mm}(\mathrm{~S} . \mathrm{D}=3 ; n=92)$; Oral disc diameter up to $18 \mathrm{~mm}$, typically $8 \mathrm{~mm}(\mathrm{~S} . \mathrm{D}=3 ; n=94)$. Column $\sim 12 \mathrm{~mm}$ in height in preserved specimens. Usually, tentacles not larger than oral disc diameter and to $12 \mathrm{~mm}$ long in preserved specimens.

Coloration.- Oral disc, column and tentacles chocolate or sepia brown, varying from olive green to grayish ochre. Rarely tentacles white to greenish or translucent blue and column of a pale orange tone (var. eton, Fig. 5). Proximal column and pedal disc often lighter in color than rest of the body. Frequently, oral disc with opaque marks over mesenterial insertions forming a stellate pattern of radial stripes around mouth (Fig. 2A). Tentacles may also present an opaque base and/or greenish-white spots (Fig. 2B). Preserved specimens discolor to grayish or yellowish tones depending on fixative solution. 

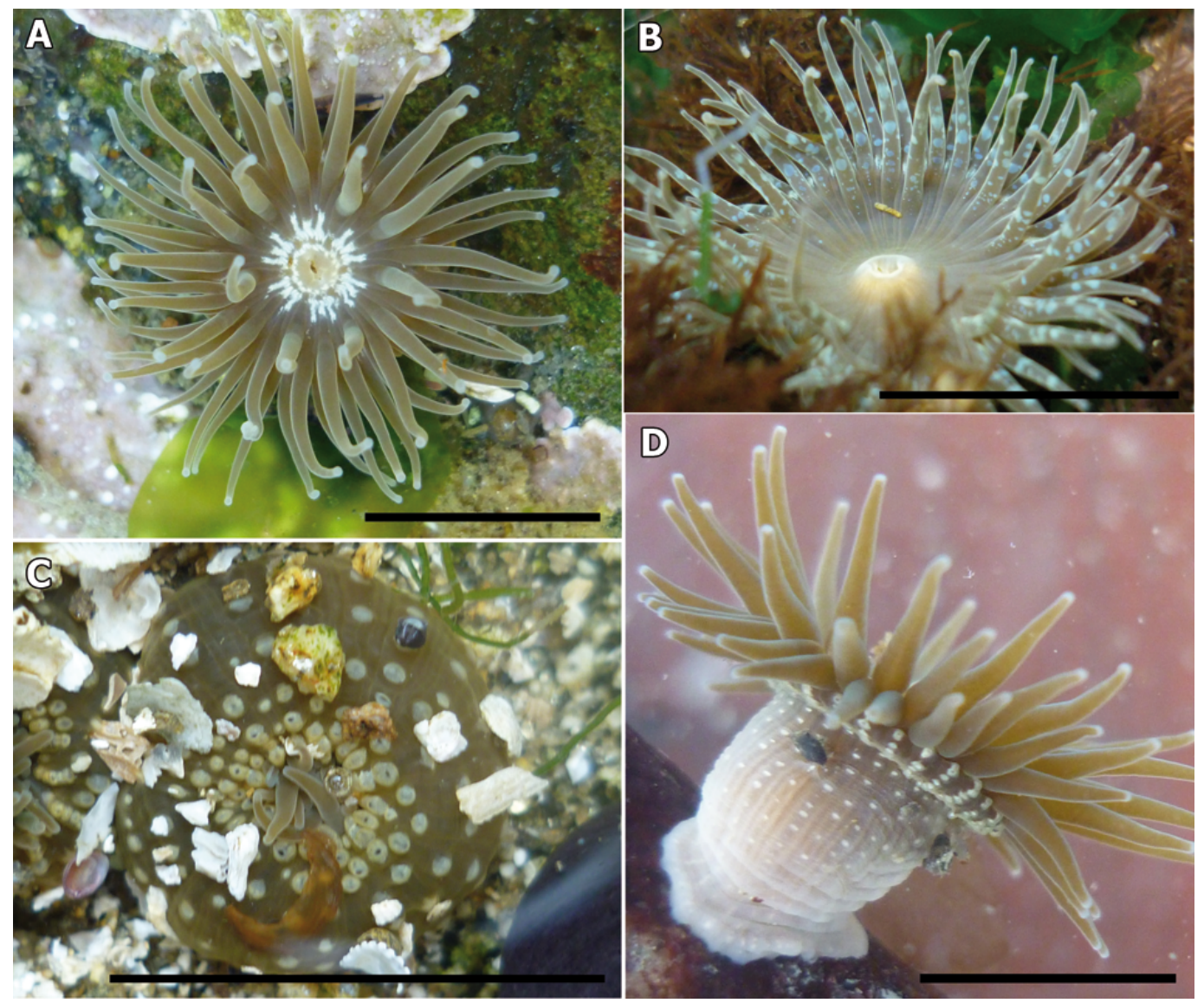

Figure 2. Anthopleura hermaphroditica. A-B) Oral disc view; C) Oral view of contracted specimen; D) Lateral view of column. Scale: $8 \mathbf{~ m m ~ / ~ A n t h o p l e u r a ~ h e r m a p h r o d i t i c a . ~ A - B ) ~ V i s t a ~ d e l ~ d i s c o ~ o r a l ; ~ C ) ~ V i s t a ~ o r a l ~ d e ~ u n ~ e s p e ́ c i m e n ~}$ contraído; D) Vista lateral de la columna. Escala: $8 \mathrm{~mm}$

Column.- Provided with numerous small, endocoelic, adhesive verrucae, generally arranged in 24 well-defined longitudinal rows. These can be more or less developed and, in many cases, may be slightly pigmented. Rows of verrucae are distributed regularly throughout the column but are more prominent distally (Fig. 2D). Each row with a marginal projection that can bear up to five verrucae on its outer surface. Half of the specimens also exhibited an opaque, swollen acrorhagus on the inner edge of up to 1 $\mathrm{mm}$ diameter (Fig. 3E); with deep fosse.

Oral disc and tentacles.- Mouth more or less prominent and may be elevated on oral cone or lip. Tentacles between 19-68 (in a $2 \mathrm{~mm}$ and $17 \mathrm{~mm}$ pedal disc specimens, respectively) in number, slender, conical, generally short, with rounded and, occasionally, perforated tip; hexamerously arranged in two to five cycles, the last one never complete. Tentacles can be fully covered by the column when contracted (Fig. 2C).

Pedal disc.- Distinct limbus and usually arcuate inwards in preserved organisms. Pedal disc adherent and well-developed.

Internal anatomy: General.- Actinopharynx no longer than half length of the column, deeply sulcated, with two well-developed aborally prolonged siphonoglyphs, each attached to a pair of directives (Fig. 3C). Oral and marginal stomata present, the latter usually reduced. Mesenteries hexamerously arranged in three perfect cycles, even though occasionally individuals with less than 24 pairs or with a fourth cycle in early development may be found. Mesenteries grow from the pedal disc upward (with more mesenteries proximally than distally). In most specimens, the reproductive tissue was poorly developed and only observed in the first 2 cycles. 


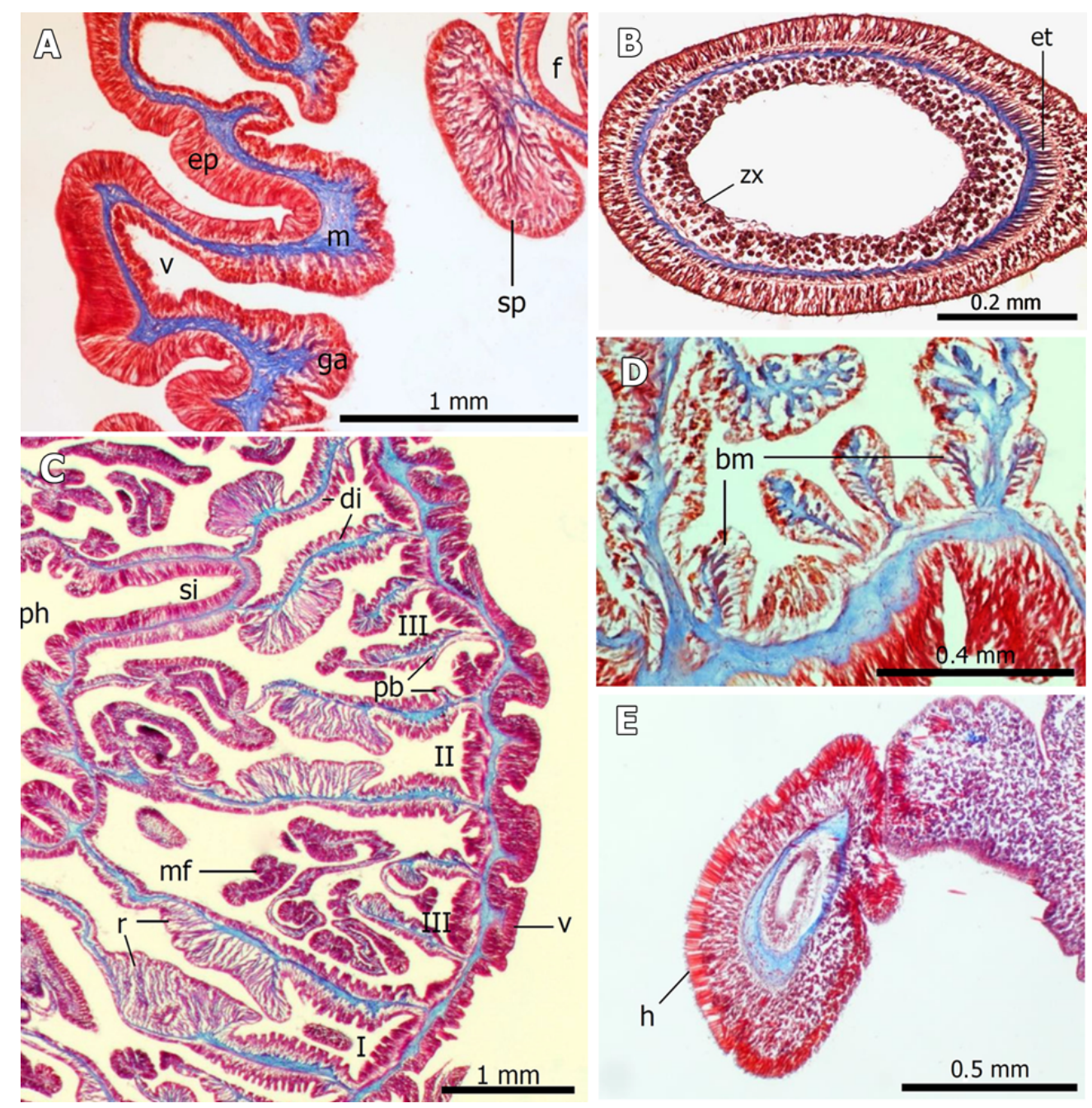

Figure 3. Anthopleura hermaphroditica anatomy. A) Longitudinal section of margin; B) Cross section of tentacle; C) Cross section of upper column; D) Longitudinal section of pedal disc; E) Longitudinal section of an acrorhagi. I, II and III: $1^{\text {st }}$ to $3^{\text {rd }}$ cycle of mesenteries, ph: actinopharynx, di: directives, mf: mesenterial filaments, pb: parietobasilar muscle, r: retractor muscle, si: siphonoglyph, v: verruca, sp: sphincter, ep: epidermis, $\mathrm{f}$ : fosse, ga: gastrodermis, $\mathrm{m}$ : mesoglea, et: ectodermal longitudinal muscle of tentacle, zx: zooxanthellae, bm: basilar muscle, h: holotrichs battery / Anatomía de Anthopleura hermaphroditica. A) Corte longitudinal del margen; B) Corte transversal de un tentáculo; C) Corte transversal de la columna superior; D) Corte longitudinal del disco pedio; E) Corte longitudinal de un acrorragio. I, II y III: $1^{\text {er a }} 3^{\text {er }}$ ciclo de mesenterios, ph: actinofaringe, di: directivos, mf: filamento mesenterial, pb: músculo parietobasilar, $\mathrm{r}$ : músculo retractor, si: sifonoglifo, $\mathrm{v}$ : verruga, sp: esfinter, ep: epidermis, f: fosa, ga: gastrodermis, $\mathrm{m}$ : mesoglea, et: músculo longitudinal ectodérmico del tentáculo, zx: zooxantelas, bm: músculo basilar, h: bateria de holotricos

Musculature.- Marginal sphincter muscle endodermal, circumscribed-pinnate with highly branched mesogleal processes (Fig. 3A). Circular endodermal musculature of body wall strong but absent in verrucae. Longitudinal muscles of tentacles ectodermal (Fig. 3B). Retractor muscles diffuse, strong and often covering half of the mesentery. Basilar and pariertobasilar muscles welldefined and more or less strong (Figs. 3C, D).
Cnidom: Spirocysts, basitrichs, rod-like basitrichs, holotrichs, microbasic $b$-mastigophores and microbasic $p$-mastigophores A1, A2 (Fig. 4). See Table 1 for size and distribution of cnidae.

It should be noted that the rod-like basitrichs only appeared in larger numbers in specimens collected between Coquimbo and Antofagasta, and sometimes were observed in the gastrodermis of the tentacles. Significant differences 


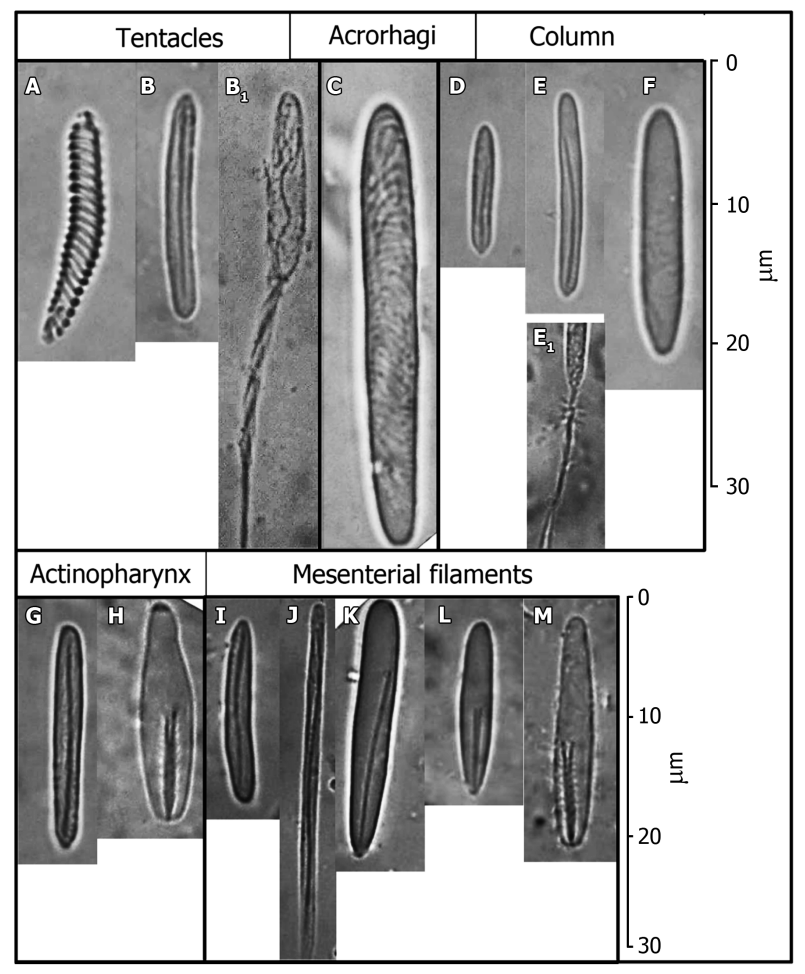

Figure 4. Cnidae of Anthopleura hermaphroditica. A-M letters refer to Table 1 / Cnidos de Anthopleura hermaphroditica. Letras A-M referidas a la Tabla 1
( $\alpha=0.05, P<0.001$ ) were found in the capsule length of basitrichs, holotrichs and microbasic $p$-mastigophores A1 between populations. Major differences in standard deviation occurred between populations from the centralsouth (Chiloé, Puerto Montt and Concepción) and northern regions (Coquimbo, Caldera and Antofagasta).

Distribution and habitat: Anthopleura hermaphroditica can be found in the intertidal and shallow subtidal (to 20 $\mathrm{m}$ depth) of protected or semi-protected fronts from Antofagasta $\left(23^{\circ} 39^{\prime} \mathrm{S}, 7^{\circ} 25^{\prime} \mathrm{W}\right)$ to the Chonos

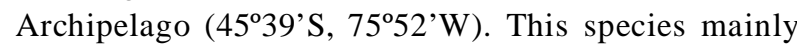
inhabits tide pools, frequently lives under rocks, in crevices and very often on mussels or encrusting algae. Abundant on hard substrate, the highest densities (>> 1000 ind. $\mathrm{m}^{-2}$ ) were reached in fine or muddy sand flats, forming extended carpets of tentacles (Bahía de Quellón, Punta Metri, Bahía Quillaipe and Puntilla de Coliumo). Usually, specimens shared habitat with other sea anemones, such as Bunodactis hermafroditica (Carlgren, 1959), juveniles of Phymactis papillosa (Lesson, 1830) and Paranthus niveus (Lesson, 1830) (the latter only in soft bottoms with hard substrate below).

Table 1. Capsules size and distribution of cnidae of Anthopleura hermaphroditica and Bunodactis hermafroditica. ' $m_{1}$ ' and ' $m_{w}$ ' are the means, ' $d$ ' and ' $d_{w}$ ' are the standard deviations (all in $\mu \mathrm{m}$ ), ' $N$ ' is the proportion of animals examined with respective type of cnidae present and ' $n$ ' is the number capsules measured / Tamaño de las cápsulas y distribución de los cnidos en Anthopleura hermaphroditica y Bunodactis hermafroditica. ' $m_{1}$ ' $y$ ' $m_{w}$ ' son los promedios, ' $d_{1}$ ' $y$ ' $d_{w}$ ' son las desviaciones estándar (todo en $\mu \mathrm{m}$ ), ' $N$ ' es la proporción de animales examinados con el respectivo tipo de cnidocisto presente $y$ ' $n$ ' es el número de capsulas medidas

\begin{tabular}{|c|c|c|c|c|c|c|c|c|c|c|c|c|c|c|c|c|c|c|}
\hline \multirow[t]{2}{*}{ Tissue } & \multirow[b]{2}{*}{ Cnidae } & \multicolumn{8}{|c|}{ Anthopleura hermaphroditica } & \multirow[b]{2}{*}{ Cnidae } & \multicolumn{8}{|c|}{ Bunodactis hermafroditica } \\
\hline & & Length & $\mathrm{m}_{1}$ & $d_{1}$ & Width & $\mathrm{m}_{\mathrm{w}}$ & $d_{w}$ & $N$ & $n$ & & Length & $\mathrm{m}_{1}$ & $d_{1}$ & Width & $\mathrm{m}_{\mathrm{w}}$ & $\mathrm{d}_{\mathrm{w}}$ & $N$ & $n$ \\
\hline \multirow[t]{2}{*}{ Tentacle } & Spirocyst (A) & $9.3-23.8$ & 15.9 & 2.5 & $1.5-3.1$ & 2.3 & 0.3 & $24 / 24$ & 690 & Spirocyst $(\mathrm{N})$ & $9.7-24.2$ & 16.2 & 3.3 & $1.5-2.8$ & 2.1 & 0.3 & 9/9 & 280 \\
\hline & Basitrich 2 (B) & $12.5-22.4$ & 16.4 & 1.4 & $1.5-2.8$ & 2.2 & 0.2 & $24 / 24$ & 665 & Basitrich $2(\mathrm{O})$ & $12.8-22.3$ & 17.5 & 1.7 & $1.7-3.1$ & 2.4 & 0.3 & 9/9 & 280 \\
\hline Acrorhagi & Holotrich (C) & $19.2-44.7$ & 34.0 & 4.8 & $2.2-6.2$ & 4.0 & 0.7 & $16 / 16$ & 538 & & & & & & & & & \\
\hline \multirow[t]{3}{*}{ Column } & Basitrich 1 (D) & $8.3-13.0$ & 10.4 & 1.0 & $1.3-2.1$ & 1.7 & 0.2 & $15 / 26$ & 100 & Basitrich $2(\mathrm{P})$ & $9.1-20.8$ & 14.0 & 2.0 & $1.2-3.0$ & 2.1 & 0.3 & $7 / 7$ & 240 \\
\hline & Basitrich 2 (E) & $10.0-19.3$ & 14.0 & 1.5 & $1.6-2.9$ & 2.1 & 0.2 & $26 / 26$ & 686 & & & & & & & & & \\
\hline & Holotrich (F) & $12.3-24.2$ & 17.5 & 2.3 & 2.14 .5 & 3.2 & 0.4 & $24 / 26$ & 420 & & & & & & & & & \\
\hline \multirow[t]{2}{*}{ Actinopharynx } & Basitrich 2 (G) & $11.1-26.1$ & 20.6 & 2.5 & $1.6-3.2$ & 2.4 & 0.3 & $21 / 21$ & 655 & Basitrich 2 (Q) & $11.0-33.0$ & 20.2 & 7.3 & $1.5-3.3$ & 2.5 & 0.4 & $5 / 5$ & 190 \\
\hline & $\begin{array}{l}\text { Microbasic } p \text { - } \\
\text { mastigophore A2 }(\mathrm{H})\end{array}$ & $14.4-21.4$ & 17.7 & 1.2 & $2.8-4.9$ & 4.0 & 0.4 & $19 / 21$ & 166 & $\begin{array}{l}\text { Microbasic } p \text { - } \\
\text { mastigophore A2 (R) }\end{array}$ & $17.6-23.2$ & 20.5 & 1.1 & $2.5-4.0$ & 3.4 & 0.3 & $5 / 5$ & 168 \\
\hline \multirow[t]{5}{*}{ Filament } & Basitrich 2 (I) & $10.8-24.8$ & 15.4 & 1.9 & $1.5-3.3$ & 2.1 & 0.2 & $22 / 22$ & 510 & Basitrich 2 (S) & $11.8-25.3$ & 14.6 & 2.5 & $1.6-2.9$ & 2.2 & 0.3 & $7 / 7$ & 107 \\
\hline & Rod-like basitrich (J) & $19.0-40.7$ & 30.7 & 3.8 & $1.1-2.0$ & 1.4 & 0.2 & $10 / 22$ & 74 & $\begin{array}{l}\text { Microbasic } b \text { - } \\
\text { mastigophore (T) }\end{array}$ & $20.7-30.0$ & 25.4 & 1.7 & $2.9-4.9$ & 3.7 & 0.4 & $7 / 7$ & 260 \\
\hline & $\begin{array}{l}\text { Microbasic } b \text { - } \\
\text { mastigophore (K) }\end{array}$ & $15.9-29.5$ & 24.1 & 2.1 & $2.7-4.9$ & 3.7 & 0.4 & $22 / 22$ & 622 & $\begin{array}{l}\text { Microbasic } p \text { - } \\
\text { mastigophore A2 (U) }\end{array}$ & $17.1-25.3$ & 21.3 & 1.5 & $2.4-4.4$ & 3.3 & 0.3 & $7 / 7$ & 192 \\
\hline & $\begin{array}{l}\text { Microbasic } p- \\
\text { mastigophore A1 (L) }\end{array}$ & $12.1-19.8$ & 15.8 & 1.2 & $2.0-3.9$ & 2.7 & 0.3 & $22 / 22$ & 470 & Large basitrich (V) & $42.3-59.1$ & 50.6 & 2.7 & $2.7-4.9$ & 3.8 & 0.3 & $7 / 7$ & 247 \\
\hline & $\begin{array}{l}\text { Microbasic } p \text { - } \\
\text { mastigophore A2 (M) }\end{array}$ & $15.1-24.4$ & 19.6 & 1.6 & $2.8-5.3$ & 3.9 & 0.4 & $22 / 22$ & 521 & & & & & & & & & \\
\hline
\end{tabular}


Natural history: Column generally with small stones pebbles and shells attached. Specimens rarely dry up and may spend several hours out of water. Under unfavorable conditions they can detached from the substrate by inflating the pedal disc. Zooxanthellae (Symbiodinium spp.) clearly present in the gastrodermis, measuring about $8.3 \mu \mathrm{m}(\mathrm{S} . \mathrm{D}=1 ; n=160)$ in diameter in the tentacles. Though most abundant there, zooxanthellae were also observed in the distal column, acrorhagi, actinopharynx and mesenterial filaments. There was significantly less zooxanthellae in specimens of the var. eton than in normal specimens. Shells of isopods of the family Cirolanidae and ischyrocerids amphipods were commonly found inside the coelenteron. No food was recognized in the specimens collected from soft bottoms.

Anthopleura hermaphroditica is a simultaneous hermaphrodite species producing both male and female gametes in different follicles of the same mesentery. Occasionally, eggs were found in the gastrovascular cavity of the tentacles (Fig. 5). Embryos appeared frequently in the coelenteron, with up to six individuals in an adult specimen. The size of the brooded young ranged between 1 and $2.5 \mathrm{~mm}$ in column diameter. During the anesthetization, some specimens everted the actinopharynx, expelling the juveniles contained inside. In the field, it is common to find several juveniles attached to the pedal disc of a larger individual.
BunodaCtis Verrill, 1899

Actiniidae with well-developed pedal disc. Whole or most of the column with adhesive verrucae, that may or may not be arranged in obvious vertical rows. No acrorhagi present, but there may be marginal projections. Tentacles rather short, simple and with ecto or meso-ectodermal longitudinal muscles. Commonly two well-developed siphonoglyphs, each attached to a pair of directives. Marginal sphincter muscle circumscribed; retractor muscles diffuse or restricted. All stronger mesenteries fertile, although sometimes the directives are sterile. Mesenteries more numerous proximally than distally. Cnidom: spirocysts, basitrichs, microbasic $\boldsymbol{b}$ mastigophores, microbasic $p$-mastigophores. (Amended diagnosis from Carlgren 1949, with changes in bold; See discussion)

\section{BUNodactis Hermafroditica (CARLGREN, 1959)}

NOT Cribrina hermaphroditicus McMurrich 1904: 287-289.

Bunodactis hermafroditica: Carlgren 1959: 23; Carter 1965: 138-139 (in part).

Bunodactis hermaphroditica: NOT Pax 1926: 26; Häussermann 1998: 92-99; Häussermann \& Försterra 2009: 255 (in part).

Gyractis hermafroditica: Sanamyan et al. 2009: 320322.

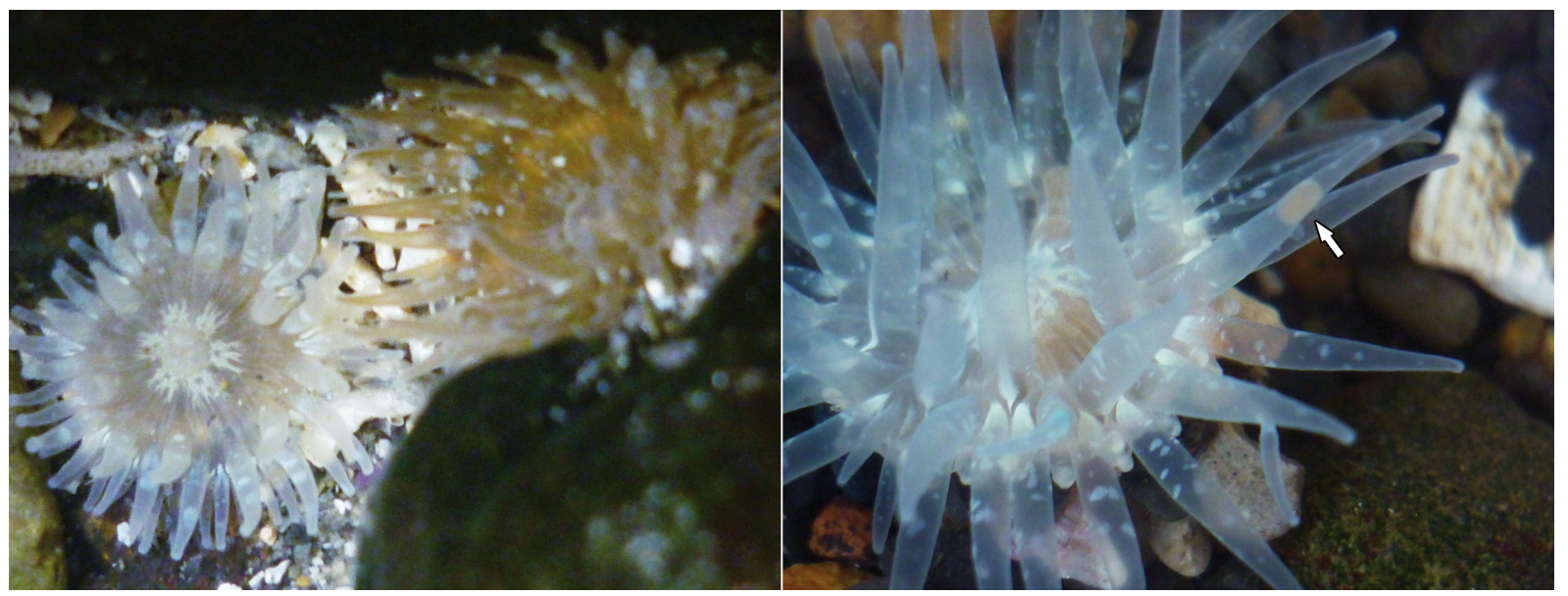

Figure 5. Var. eton. Note egg (arrow) in the gastrovascular cavity of the tentacle / Var. eton. Nótese la presencia de un huevo (flecha) en la cavidad gastrovascular del tentáculo 
Examined material (all from intertidal): 1 specimen (CS's ownership) Playa Merquiche (S12: 36 $\left.29^{\prime} \mathrm{S} ; 7^{\circ} 54^{\prime} \mathrm{W}\right)$, 15.4.2012; 3 specimen (ZSM 20130513; Neotype) Playa Cocholgüe (S14: 36³6'S; 7258'W), 12.4.2012; 1 specimen

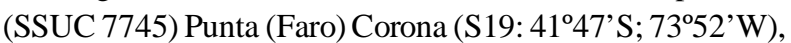
25.3.2012; 3 specimen (ZSM 20130514) Punta (Faro) Corona (S19: 4147'S; 7352'W), 25.3.2012; 1 specimen (SSUC 7745) Playa Arena Gruesa (S20: 4151'S; 7349'W), 24.3.2012.

Differential diagnosis: Medium to small size, thick cylinder-shaped species with oral disc about the same diameter as pedal disc, up to $21 \mathrm{~mm}$. Body in pastel tones of green, red and blue, with thin white radial lines around mouth. Well-developed verrucae fully cover the column with particles from surrounding environment. Marginal sphincter circumscript and retractor muscles diffuse. Viviparous.

External anatomy: Size.- Pedal disc diameter up to $21 \mathrm{~mm}$, typically $11 \mathrm{~mm}(\mathrm{~S} . \mathrm{D}=4 ; n=26)$. Column $\sim 12 \mathrm{~mm}$ in height in preserved organisms. Tentacles usually not larger than oral disc diameter and approximately $9 \mathrm{~mm}$ in living specimens.
Coloration.- Oral disc and tentacles varying between olive-brown, carmine red and dark shades of blue. Variable number of distinct, thin white radial lines on the oral disc, extending from the lip, typically yellow-orange, toward the tentacle base (Figs. 6A-C). Column generally of same color as oral disc but in paler tones, especially in proximal region. Preserved specimens cream or beige in color depending on fixative solution.

Column.- With simple, well-developed, endocoelic, adhesive verrucae, profusely distributed from margin to limbus and arranged in 24 more or less defined longitudinal rows. Because of its size, the alignment is only recognizable in living and pigmented specimens. Distal verrucae may be slightly thickened, but never with acrorhagi; with deep fosse.

Oral disc and tentacles.- Mouth more or less prominent. Tentacles commonly slender and conical; tip rounded with a terminal pore; hexamerously arranged in three to four marginal cycles. Tentacles can be fully covered by the column when contracted.

Pedal disc.- Very pronounced limbus and pedal disc adherent and well-developed.

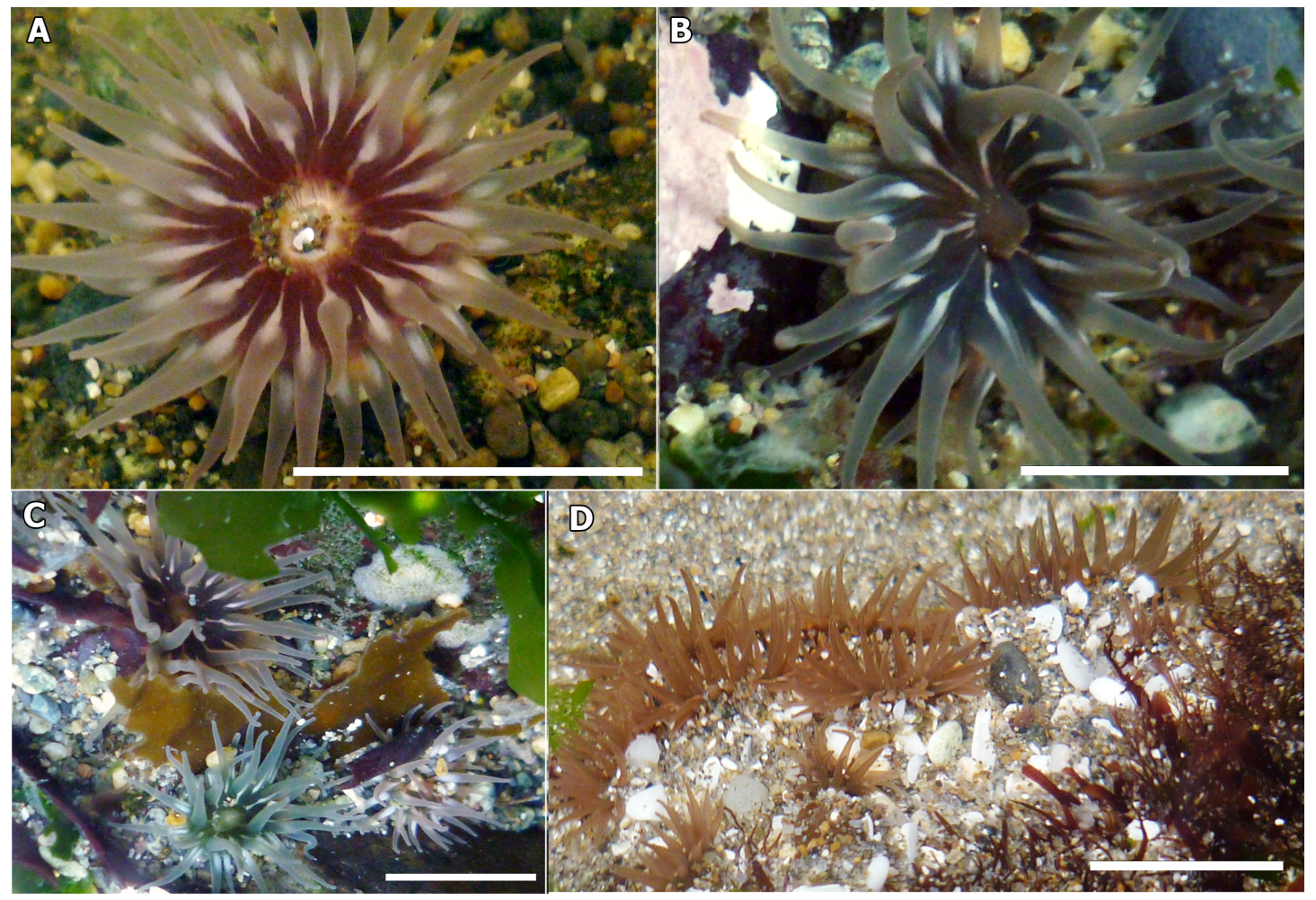

Figure 6. Bunodactis hermafroditica. A-C) Oral disc view; D) Lateral view of column of several specimens. Scale: $8 \mathrm{~mm}$ / Bunodactis hermafroditica. A-C) Vista del disco oral; D) Vista lateral de la columna de varios especímenes. Escala: $8 \mathrm{~mm}$ 
Internal anatomy: General.- Actinopharynx elevated, with longitudinal furrows up to three quarters of column length. Two siphonoglyphs prolonged to aboral region, each attached to a pair of directives (Fig. 7B). Oral and marginal stomata present but difficult to observe in contracted specimens. Mesenteries hexamerously arranged in three to four cycles, typically 24 pairs perfect. More mesenteries proximally than distally. No gametogenic tissue was observed in examined specimens.

Musculature.- Marginal sphincter muscle endodermal, circumscribed-pinnate with numerous mesogleal processes with fan-like branching pattern (Fig. 7A). Circular musculature of the body wall endodermal and longitudinal muscles of tentacles ectodermal (Fig. 7D). Retractor muscles diffuse to diffuse-restricted, very strong and highly branched. Basilar and parietobasilar muscles strong; the latter more developed proximally (Fig. 7B,C).

Cnidom: Spirocysts, basitrichs, microbasic $b$-mastigophores and microbasic $p$-mastigophores A2 (Fig. 8). See Table 1 for size and distribution of cnidae.

Additionally, the mesenterial filaments are loaded with a distinct long thick basitrich (Fig. 8V), especially abundant in the cnidoglandular tract. The basitrichs in the actinopharynx from specimens collected in the Concepción region are twice as large as those from Chiloé. Significant differences $(\alpha=0.05, P<0.001)$ were found between the basitrichs (except those of the filaments) and microbasic $b$-mastigophores of the specimens from Concepción and Chiloé Island.

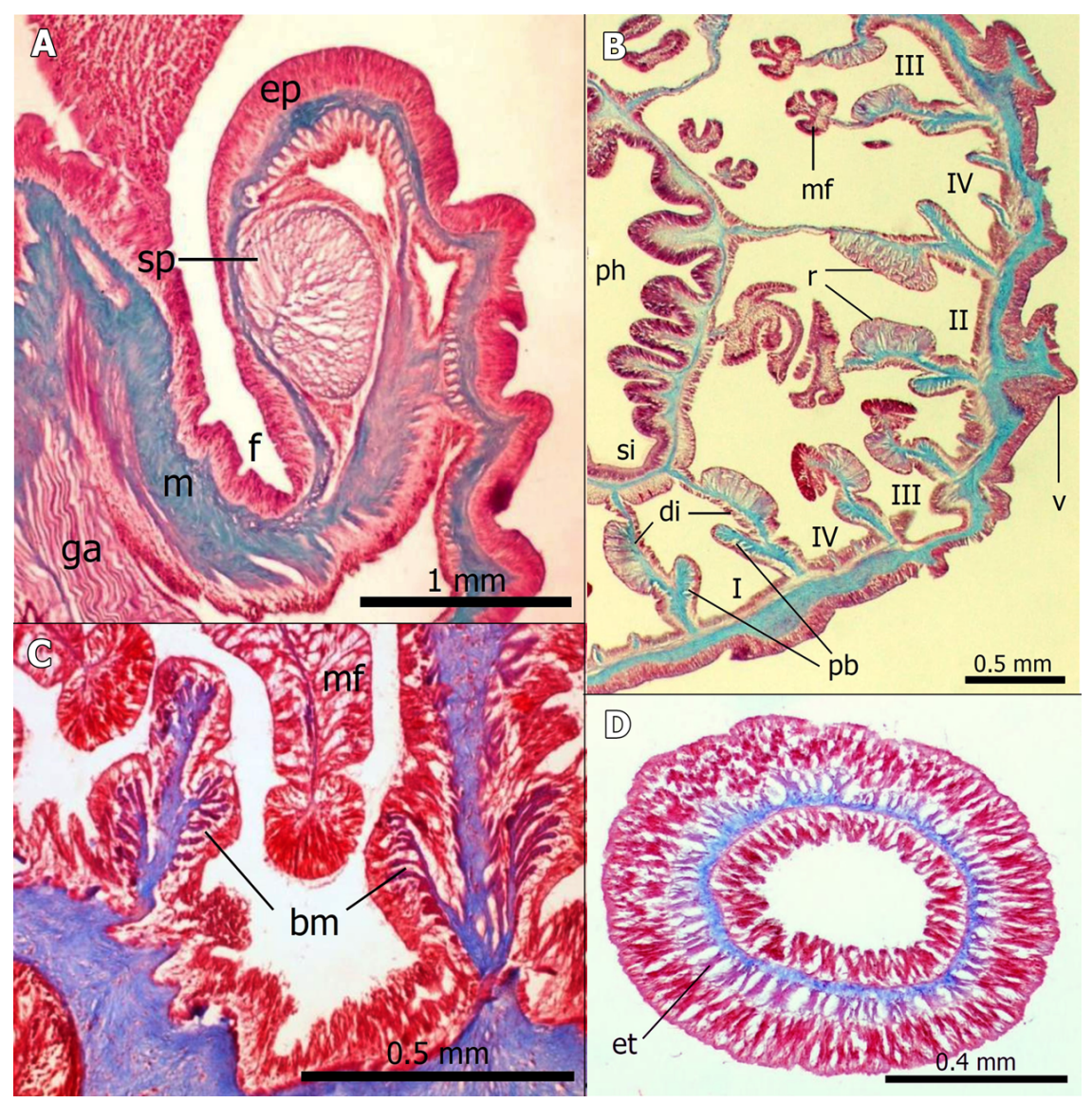

Figure 7. Bunodactis hermafroditica anatomy. A) Longitudinal section of margin; B) Cross section of upper column; C) Longitudinal section of pedal disc; D) Cross section of tentacle. I, II, III and IV: $1^{\text {st }}$ to $4^{\text {th }}$ cycle of mesenteries, ph: actinopharynx, di: directives, mf: mesenterial filaments, pb: parietobasilar muscle, r: retractor muscle, si: siphonoglyph, v: verruca, sp: sphincter, ep: epidermis, f: fosse, ga: gastrodermis, m: mesoglea, et: ectodermal longitudinal muscle of tentacle, bm: basilar muscle / Anatomía de Bunodactis hermafroditica. A) Corte longitudinal del margen; B) Corte transversal de la columna superior; C) Corte longitudinal del disco pedio; D) Corte transversal de un tentáculo. I, II, III y IV: $1^{\text {er }}$ a $4^{\text {to }}$ ciclo de mesenterios, ph: actinofaringe, di: directivos, mf: filamento mesenterial, b: músculo parietobasilar, $\mathrm{r}$ : músculo retractor, si: sifonoglifo, v: verruga, sp: esfinter, ep: epidermis, f: fosa, ga: gastrodermis, m: mesoglea, et: músculo longitudinal ectodérmico del tentáculo, bm: músculo basilar 


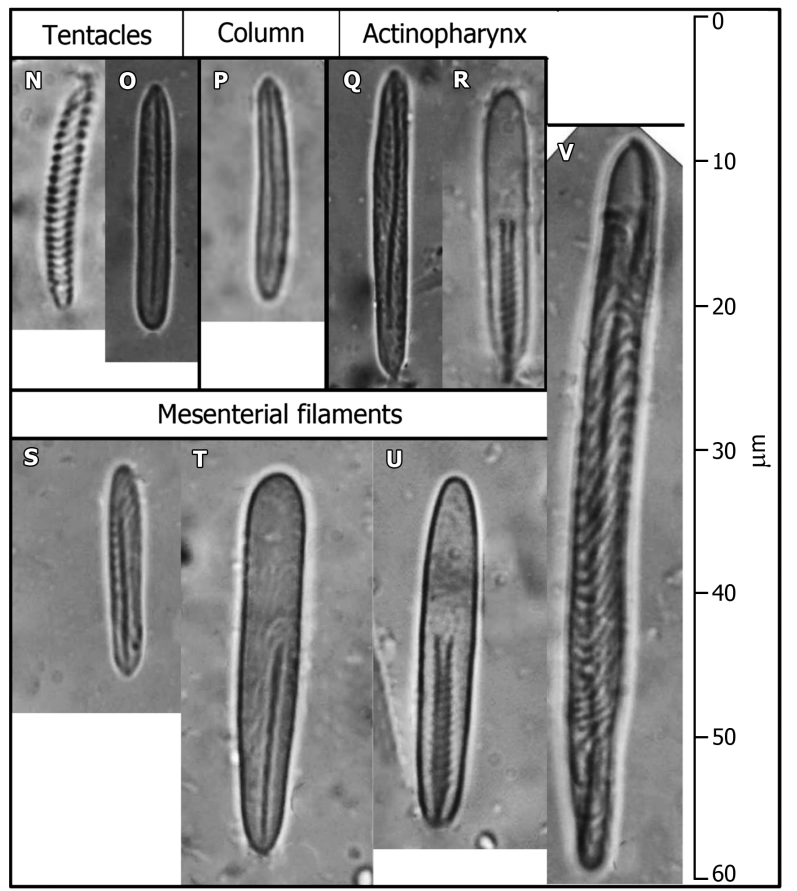

Figure 8. Cnidae of Bunodactis hermafroditica. $\mathrm{N}-\mathrm{V}$ letters refer to Table 1 / Cnidos de Bunodactis hermafroditica. Letras $\mathrm{N}-\mathrm{V}$ referidas a la Tabla 1
Distribution and habitat: Bunodactis hermafroditica can be found in the intertidal of protected or semi-protected

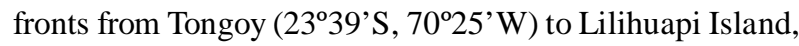
Comau Fjord $\left(42^{\circ} 14^{\prime} \mathrm{S}, 72^{\circ} 58^{\prime} \mathrm{W}\right)$. Although rather uncommon, this species lives in populations of dozens of individuals. It settles only on rocky bottoms, inhabiting tide pools, crevices, often between mussels or burrowed in thick sand. In general, B. hermafroditica was not observed co-existing with other sea anemones, except occasionally with Anthopleura hermaphroditica.

Natural history: Shell debris and pebbles adhere to verrucae fully covering the column (Fig. 6D) and preventing the body from drying (see Hart \& Crowe 1977). Azooxanthellae species. Due the presence of embryos in the coelenteron, we rarely found food inside the specimens and nothing could be taxonomically identified.

We could not confirm the hermaphroditism in Bunodactis hermafroditica because specimens did not have any reproductive tissue developed. However, most examined specimens presented numerous embryos in the coelenteron and under the pedal disc. In the pedal disc, up to 20 specimens were found hanging from the adult through small basal incisions where the embryonic envelope is attached. Embryos ranged between 1.5 and 4 $\mathrm{mm}$ in column diameter. Several specimens expelled their brooded young through the actinopharynx during anesthetization. In the field, larger individuals usually had attached several juveniles to their pedal disc.

Table 2. Diagnostic comparison between Anthopleura hermaphroditica and Bunodactis hermafroditica / Comparación diagnósticas entre Anthopleura hermaphroditica y Bunodactis hermafroditica

\begin{tabular}{lll}
\hline & Anthopleura hermaphroditica & Bunodactis hermafroditica \\
\hline $\begin{array}{l}\text { External anatomy } \\
\begin{array}{l}\text { Oral disc pigmentation } \\
\text { Body structures }\end{array}\end{array}$ & $\begin{array}{l}\text { Stellate pattern of opaque marks } \\
\text { Verrucae in well-defined rows. } \\
\text { Can bear acrorhagi }\end{array}$ & $\begin{array}{l}\text { Reduced to thin white lines } \\
\text { Verrucae developed in less defined } \\
\text { rows. Never with acrorhagi }\end{array}$ \\
$\begin{array}{ll}\text { Biology } \\
\begin{array}{l}\text { Zooxanthellae } \\
\text { Reproduction }\end{array}\end{array}$ & $\begin{array}{l}\text { Present } \\
\text { Hermaphrodite }\end{array}$ \\
$\begin{array}{l}\text { Column margin } \\
\text { Mesenterial filaments }\end{array}$ & $\begin{array}{l}\text { Holotrichs } \\
\text { Microbasic } p \text {-mastigophore A1 }\end{array}$ & - \\
\end{tabular}




\section{Discussion}

When Carlgren described Bunodes hermaphroditicus from the coast of Talcahuano, Chile, he reported the presence of acrorhagi ('marginal spherules loaded with nematocysts') in the distal column (Carlgren 1899: 23). Unable to confirm this particular character on very similar specimens, McMurrich (1904) changed the generic assignment of the species to Cribrina, partly attributing the differences to the fact that 'Carlgren's specimens were apparently about twice as large as those I examined' (McMurrich 1904: 288). Carlgren (1927) assumed that the marginal spherules will only be evident in adult organisms and sure of their conspecificity, he synonymized both species as Anthopleura hermaphroditica. Until then, descriptions provided little information about the cnidae; however, all had confirmed the presence of zooxanthellae in the gastrodermis, viviparity and the hermaphroditism of the species. During the Lund Expedition in Chile, Carlgren noticed adult organisms (with embryos inside) of $4 \mathrm{~mm}$ height, which seems make him questioned his prior assumption. In his last manuscript, Carlgren (1959) returned to differentiate his specimens from those of McMurrich only via the presence of acrorhagi and, probably by error, he used the spelling with $f$ (hermafroditica) instead of $p h$.

Despite having very similar descriptions, Anthopleura hermaphroditica can be distinguished from Bunodactis hermafroditica in both macroscopic and microscopic features (Table 2). Externally, both species differ in color pattern and the verrucae size. In $B$. hermafroditica, for instance, the oral disc pigmentation is rather reduced while the verrucae are much more developed than in $A$. hermaphroditica. The latter is easily verifiable in the field, where specimens of $B$. hermafroditica remain completely covered by the surrounding material, compared to $A$. hermaphroditica that is usually covered partially or, in mudflats, not at all. Furthermore, only A. hermaphroditica specimens are zooxanthellate and, even though both species incubate their offspring, we could not confirm the hermaphroditism of $B$. hermafroditica. The scarce development of gametogenic tissue observed in most of the specimens could indicate the occurrence of a gamete emission period between spring and early summer, as it is with other brooding species (Fautin \& Sebens 1987). In their redescription of A. hermaphroditica, Yanagi \& Daly (2004) stated that mesenteries of specimens containing many brooded young typically lack gametogenic tissue, which would be more marked between January and April (Schories et al. 2011).
There are 3 main differences between the cnidom of the two species: the presence of holotrichs (Fig. 4C,F) in the column and microbasic $p$-mastigophores A1 in the filaments (Fig. 4L) of Anthopleura hermaphroditica and the presence of a large basitrich (Fig. 8V) in the filaments of Bunodactis hermafroditica. Mastigophores designations are based on Schmidt's papers $(1972,1974)$ about cnidae and, particularly, the microbasic $b$-mastigophores is termed according the b-Rhabdoid III of Schmidt (1972). Similarly, the holotrich listed here for the column of $A$. hermaphroditica probably refers to the heterotrich mentioned by Yanagi \& Daly (2004) and Schories et al. (2011) as a diagnostic feature of the genus Anthopleura (see England 1987). However, we could not verify the identity of this cnidae in discharged capsules and therefore, prefer to use the more general term holotrich. In fact, several ultrastructure differences between the nematocysts are hardly recognizable by light microscopy and can lead to false interpretations if not compared with higher resolution examinations (Östman 2000). As for their size, basitrichs were the most variable nematocysts among populations of both species, followed by holotrichs for $A$. hermaphroditica and microbasic $b$-mastigophores for $B$. hermafroditica. Because these measures are related to body size within anemone species (see Ardelean \& Fautin 2004), its taxonomic value has been debated in recent years (Williams 1998, 2000) for being probably an adaptive character (Francis 2004). Yet, the length of the microbasic p-mastigophores A2 were markedly constant in both species, showing little variation between sampling areas.

Based on this comparison, much of the previous determinations must be emended. The specimens identified by McMurrich (1904), as Cribrina hermaphroditica, and by Pax (1926), as Bunodactis hermaphroditica, belong to the species Anthopleura hermaphroditica described by Carlgren (1899) as having zooxanthellae in the gastrodermis. The voucher specimens on which Carlgren (1959) based his identification of Bunodactis hermafroditica were found poorly preserved and, although without visible acrorhagi, they have zooxanthellae in the tentacles and rod-like basitrichs in the filaments. Due to the similarity of both species in the field, Carlgren might have failed to identify $B$. hermafroditica based on preserved material (which could explain why his last description of this species is so brief). Since the characterization of $B$. hermafroditica, as a species without marginal spherules, viviparous and very variable in color, does not overlap with that of $A$. hermaphroditica, the authorship of $B$. hermafroditica 
belongs to Carlgren (1959) as being who finally recognized the species neither as a synonym nor homonym of Bunodes hermaphroditicus. To avoid further confusion, we designate a neotype for Bunodactis hermafroditica (specimens 20130513; ZSM).

England (1987) stated that Carlgren's material should be re-examined since he suspected $A$. hermaphroditica to be conspecific with $A$. handi, which is described for Malaysia and Singapore. Just by his description, $A$. handi clearly differs from $A$. hermaphroditica by having cinclides and a diffuse marginal sphincter muscle, and by being gonochoric and azooxanthellate. Nonetheless, we observed noticeable morphological differences among certain populations of $A$. hermaphroditica that had been previously reported by Häussermann (1998) for Playa La Herradura, Coquimbo, and that were included in the redescription of Yanagi \& Daly (2004) (Fig. 2D in this paper). Some characters mentioned by the latter authors (e.g., pink coloration, denticulate margin, presence of parietal muscles) could not be confirmed for $A$. hermaphroditica and were only noted for a particular morph found between 'escollo El Pulpo' (S3: 2701'S; $70^{\circ} 51^{\prime} \mathrm{W}$ ) and Puerto Aldea (S11: 30¹7'S; $\left.71^{\circ} 36^{\prime} \mathrm{W}\right)$. The degree of divergence of these specimens, in which neither zooxanthellae nor embryos were observed, preliminarily indicates a distinct and undescribed species for Chile.

In his classification of Actiniaria, Stephenson (1921) criticizes the use of acrorhagi as being too variable structures to define families. Because they respond to inter and intraspecific aggressive behaviors (Bigger 1980), their development is associated with ecological parameters such as competition for space (Francis 1973a, 1973b, 1976, Ayre \& Grosberg 1995). Our observations of Anthopleura hermaphroditica support this hypothesis by comparing the size of the acrorhagi between specimens collected from sites with abundant anemones with those from soft bottoms where, apparently, there are neither predators nor competitors (Schories et al. 2011). Since the identification of the species was based on the presence or absence of acrorhagi, their variability explains why both species had been repeatedly mistaken on later descriptions (e.g., Carter 1965). Furthermore, molecular studies concur that Anthopleura is not monophyletic (McCommas 1991, Geller \& Walton 2001, Daly 2004b, Daly et al. 2008) and that verrucae and acrorhagi are homoplasic characters (Heestand 2009). The assumption of polyphyly suggests that these structures are adaptive advantages to intertidal environment and, therefore, features that have been lost and reappeared many times in the evolutionary history of the genus (Heestand 2009).
Though it lacks clarity in diagnostic terms, the generic assignment of Bunodactis Verrill, 1899 has been also debated as a junior synonym of Aulactinia Verrill, 1864 (Dunn et al. 1980). Based on this synonymization, Sanamyan et al. (2009) proposed to move Bunodactis hermafroditica to the genus Gyractis Boveri, 1893 applying England's (1987) concept of marginal spherules. He defined these structures as all blister-shaped protuberances occurring on the margin, including both with and without nematocysts batteries. This became quite confusing as Carlgren made a clear difference between them, only naming marginal spherules those furnished with holotrichs (the rest were termed as 'pseudospherules'). According to Carlgren (1949), the genus Bunodactis not possess marginal spherules, although pseudospherules may be present. To unravel this problem, we propose to adapt these generic diagnoses to the terminology established by Daly (2003). She describes the marginal structures as a composition of two distinct parts: a projection of the upper column, termed marginal projection, and a holotrich-dense pad, termed acrorhagus, that is histologically differentiated from the surrounding tissues. Given that Bunodactis verrucosa Pennant, 1777, the type species of Bunodactis, is described with 'large well-developed marginal spherules' (England 1992: 68), the diagnosis of the genus should rather say 'No acrorhagi present, but there may be marginal projections'. Correspondingly, for Anthopleura it should be stated 'acrorhagi present', even though they might not be developed in all the specimens. Based on these criteria, the only two valid species of the genus Gyractis, G. sesere (Haddon \& Shackleton, 1893) and G. spenceri (Haddon \& Duerden, 1896) (Fautin 2013), should be moved to the genus Bunodactis since they possess basitrichal marginal projections (but no acrorhagi). This still fits with the description of Dunn et al. (1980) for Aulactinia, though they included the presence of atrichs into the diagnosis by finding this cnidae type in the tentacles of $A$. incubans Dunn, Chia \& Levine, 1980. Without examining the type material of Aulactinia, they justified the replacement of Bunodactis according to Article 60.2 of the International Code of Zoological Nomenclature: 'If the rejected junior homonym has one or more available and potentially valid synonyms, the oldest of these becomes the valid name of the taxon with its own authorship and date' (ICZN 1999). In fact, the two genera were synonymized only because Carlgren (1949) originally placed the type species Aulactinia capitata Agassiz in Verrill, 1864 in Bunodactis. In this sense, although this synonymy may be plausible via the Code, we still consider Bunodactis a valid genus until Aulactinia is further revised, integrating these concepts and including its type material to the analysis. 


\section{ACKNOWLEDGments}

We are very grateful to Veronica Flores, Patricio Zavala, Jeanette Santana and Jennifer Amaya for their technical and bibliographic support. It is pleasure to thank Nadya Sanamyan and Estefanía Rodríguez for their very constructive comments and suggestions on previous versions of the manuscript. Special thanks to Abigail Reft for all her help and insights on the cnidae analysis. Many thanks to Andreas Schmidt-Rhaesa and Helma Roggenbuck of the Zoologisches Museum Hamburg; Elín Sigvaldadóttir and Karin Kronestedt of the Swedish Museum of Natural History; Carsten Lüter of the Museum für Naturkunde; and Lutz Bachmann and Ase Wilhelmsen of the Natural History Museum of Oslo for loan of the type material. We also like to thank Katie McConnell for assistance with the translation of this paper. CS is particularly grateful to Marta Luz Pérez and Jose Luis Spano for all their support and help along this study. VH thanks Günter Försterra for collecting specimens during several expeditions. This publication is drawn from the graduate thesis of CS and represents publication number 88 of Huinay Scientific Field Station.

\section{LITERATURE CITED}

Ardelean A \& DG Fautin. 2004. A new species of the sea anemone Megalactis (Cnidaria: Anthozoa: Actiniaria; Actinodendridae) from Taiwan and designation of a neotype for the type species of the genus. Proceedings of the Biological Society of Washington 117(4): 488-504.

Ayre DJ \& RK Grosberg. 1995. Aggression, habituation, and clonal coexistence in the sea anemones Anthopleura elegantissima. American Naturalist 146(3): 427-453.

Belém MJ \& SM Pinto. 1990. Morphological and microanatomical study of Anthopleura krebsi Duchassaing \& Michelotti, 1860 (Cnidaria, Anthozoa, Actiniidae), a new record in Brazil. Anais da Academia Brasileira de Ciências 62(2): 183-192.

Bigger CH. 1980. Interspecific and intraspecific acrorhagial aggressive behavior among sea anemones: a recognition of self and not-self. The Biological Bulletin 159: 117-134.

Carlgren O. 1899. Zoantharien. Hamburger Magelhaenische Sammelreise 4: 1-48.

Carlgren O. 1927. Actiniaria and Zoantharia. In: Odhner T (ed). Further zoological research from the Swedish Antarctic Expedition 1901-1903, pp 1-102. P.A. Norstedt \& Soner, Stockholm.

Carlgren O. 1949. A survey of the Ptychodactiaria, Corallimorpharia and Actiniaria. Kungliga Svenska Vetenskapsakademiens Handlingar 1(1): 1-121.
Carlgren O. 1959. Reports of the Lund University Chile Expedition 1948-49, Corallimorpharia and Actiniaria with description of a new genus and species from Peru. Kungliga Svenska Vetenskapsakademiens Handlingar 71(6): 1-39.

Carter D. 1965. Actinias de Montemar, Valparaíso. Revista de Biología Marina 12: 129-160.

Daly M. 2003. The anatomy, terminology, and homology of acrorhagi and pseudoacrorhagi in sea anemones. Zoologische Verhandelingen 345: 89-101.

Daly M. 2004a. Anatomy and taxonomy of three species of sea anemones (Cnidaria: Anthozoa: Actiniidae) from the Gulf of California, including Isoaulactinia hespervolita Daly, n. sp. Pacific Science 58(3): 377-390.

Daly M. 2004b. Phylogeny and biogeography of Anthopleura in the North Atlantic Ocean. Hydrobiologia 530/531: 241-248.

Daly M \& JC Den Hartog. 2004. Taxonomy, circumscription, and usage in Anthopleura (Cnidaria: Anthozoa: Actiniaria) from the Gulf of Mexico and the Caribbean. Bulletin of Marine Science 74(2): 401-421.

Daly M, A Chaudhuri, L Gusmão \& E Rodríguez. 2008. Phylogenetic relationships among sea anemones (Cnidaria: Anthozoa: Actiniaria). Molecular Phylogenetic and Evolution 48: 292-301.

Den Hartog JC. 1987. A redescription of the sea anemone Bunodosoma biscayensis (Fischer, 1874) (Actiniaria, Actiniidae). Zoologische Mededelingen 61(36): 533-559.

Dunn DF, FS Chia \& R Levine. 1980. Nomenclature of Aulactinia (= Bunodactis), with description of Aulactinia incubans n. sp. (Coelenterata: Actiniaria), an internally brooding sea anemone from Puget Sound. Canadian Journal of Zoology 58: 2071-2080.

England KW. 1987. Certain Actiniaria (Cnidaria, Anthozoa) from the Red Sea and tropical Indo-Pacific Ocean. Bulletin of the British Museum (Natural History) 53(4): 205-292.

England KW. 1991. Nematocysts of sea anemones (Actiniaria, Ceriantharia and Corallimorpharia: Cnidaria): nomenclature. Hydrobiologia 216/217: 691-697.

England KW. 1992. Actiniaria (Cnidaria: Anthozoa) from Hong Kong with additional data on similar species from Aden, Bahrain and Singapore. In: Morton B (ed). The marine flora and fauna of Hong Kong and Southern China III, pp. 49-95. Hong Kong University Press, Hong Kong.

Fautin DG. 2013. Hexacorallians of the world. <http:// geoportal.kgs.ku.edu/hexacoral/anemone2/index.cfm>

Fautin DG \& KP Sebens. 1987. Phylum Cnidaria, Class Anthozoa. In: Strathmann MF (ed). Reproduction and development of marine invertebrates of the Northern Pacific Coast, pp. 83-104. University of Washington Press, Seattle.

Francis L. 1973a. Clone specific segregation in the sea anemone Anthopleura elegantissima. The Biological Bulletin 144: 64-72. 
Francis L. 1973b. Intraspecific aggression and its effect on the distribution of Anthopleura elegantissima and some related sea anemones. The Biological Bulletin 144: 73-92.

Francis L. 1976. Social organization within clones of the sea anemone Anthopleura elegantissima. The Biological Bulletin 150: 361-376.

Francis L. 2004. Microscaling: why larger anemones have longer cnidae. The Biological Bulletin 207: 116-129.

Geller JB \& ED Walton. 2001. Breaking up and getting together: evolution of symbiosis and cloning by fission in sea anemones (genus Anthopleura). Evolution 55(9): 17811794.

Hart CE \& JH Crowe. 1977. The effect of attached gravel on survival of intertidal anemones. Transactions of the American Microscopical Society 96(1): 28-41.

Häussermann V. 1998. Beiträge zur Aktinienfauna Chiles (Cnidaria, Anthozoa), Teil 2. Diplomarbeit, Zoologisches Institut, Universität München, Martinsried, 157 pp.

Häussermann V. 2004. Re-description of Phymactis papillosa (Lesson, 1830) and Phymanthea pluvia (Drayton in Dana, 1846) (Cnidaria: Anthozoa), two common actiniid sea anemones from the south east Pacific with a discussion of related genera. Zoologische Mededelingen 78(23): 345-381.

Häussermann V \& G Försterra. 2009. Actiniaria -Anémonas de mar. En: Häussermann V \& G Försterra (eds). Fauna marina bentónica de la Patagonia chilena, pp. 215-266. Nature in Focus, Santiago.

Heestand EN. 2009. Phylogeny and evolution of Anthopleura (Cnidaria: Anthozoa: Actiniaria). Master Thesis, Evolution, Ecology, and Organismal Biology Graduate Program, The Ohio State University, Columbus, 42 pp.

ICZN. 1999. Código internacional de nomenclatura zoológica, 156 pp. Museo Nacional de Ciencias Naturales, Madrid.

McCommas SA. 1991. Relationships within the family Actiniidae (Cnidaria: Actiniaria) based on molecular characters. Hydrobiologia 216/217: 509-512.

McMurrich JP. 1904. The Actiniæ of the plate collection. Zoologische Jahrbucher 6(2): 215-306.

Östman C. 2000. A guideline to nematocyst nomenclature and classification, and some notes on the systematic value of nematocysts. Scientia Marina 64: 31-46.
Pax F. 1926. Die Aktinien der Deutschen Südpolar-Expedition 1901-1903. Deutsche Südpolar-Expedition 1901-1903 18: 3-62.

Riemann-Zürneck K \& VA Gallardo. 1990. A new species of sea anemone (Saccactis coliumensis n. sp.) living under hypoxic conditions on the central Chilean shelf. Helgoländer Meeresuntersuchungen 44: 445-457.

Sanamyan N, K Sanamyan \& D Schories. 2009. On authorship of Chilean anemone 'Bunodactis hermafroditica' (Cnidaria: Actiniaria) and its generic assignment. Zoosystematica Rossica 18(2): 320-322.

Schmidt H. 1972. Die Nesselkapseln der Anthozoen und ihre Bedeutung fur die phylogenetische Systematik. Helgoländer Wissenschaftliche Meeresuntersuchungen 23: 422-458.

Schmidt H. 1974. On evolution in the Anthozoa. Proceedings of the Second International Coral Reef Symposium 1: 533 560 .

Schories D, K Reise, K Sanamyan, N Sanamyan, E Clasing \& A Reise. 2011. Actinian dominated intertidal mudflats: A new case of an extraordinary rare phenomenon from Southern Chile. Journal of Sea Research 65: 304-314.

Spano C \& V Flores. 2013. Staining protocol for the histological study of sea anemones (Anthozoa: Actinaria) with recommendations for anesthesia and fixation of specimens. Latin American Journal of Aquatic Research 41(5): 1019-1024.

Stephenson TA. 1921. On the classification of Actiniaria: Part II. Consideration of the whole group and its relationships, with special reference to forms not treated in Part I. Quarterly Journal of Microscopical Science 65: 493-576.

Williams RB. 1998. Measurements of cnidae from sea anemones (Cnidaria: Actiniaria), II: further studies of differences amongst sample means and their taxonomic relevance. Scientia Marina 62: 361-372.

Williams RB. 2000. Measurements of cnidae from sea anemones (Cnidaria: Actiniaria), III: ranges and other measures of statistical dispersion, their interrelations and taxonomic relevance. Scientia Marina 64: 49-68.

Yanagi K \& M Daly. 2004. The hermaphroditic sea anemone Anthopleura atodai $\mathrm{n}$. sp. (Anthozoa: Actiniaria: Actiniidae) from Japan, with a redescription of A. hermaphroditica. Proceedings of the Biological Society of Washington 117(3): 422-436.

Received 9 May 2013 and accepted 9 October 2013

Editor: Claudia Bustos D. 